Dicle Tıp Dergisi / Dicle Med J (2019) 46 (3) : 405 - 410

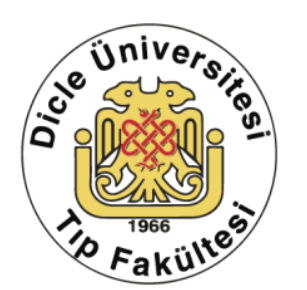

WWW.diclemedj.org

Original Article / Özgün Araştırma

\title{
Can the Urologists Perform Stone Analysis, Metabolic Evaluation and Metaphylaxis at Urinary Tract Stone Disease in Tekirdağ?
}

\author{
Cenk Yazıcı', Murat Akgül2, Ersan Arda ${ }^{3}$, Haluk Akpınar \\ 1 Department of Urology, Tekirdağ Namık Kemal University, Faculty of Medicine, Tekirdağ, Turkey ORCID: 0000000161405181 \\ 2 Department of Urology, Tekirdağ Namık Kemal University, Faculty of Medicine, Tekirdağ, Turkey ORCID: 0000000161871940 \\ 3 Department of Urology, Trakya University, Faculty of Medicine, Edirne, Turkey ORCID: 0000000254306561 \\ 4 Department of Urology, Bilim University, Faculty of Medicine, İstanbul, Turkey ORCID: 0000000158766587
}

Received: 12.12.2018; Revised: 08.05.2019; Accepted: 21.06.2019

\begin{abstract}
Objective: As the urolithiasis is an endemic situation in our country, the urologists are well-experienced about this situation. The prevention of urolithiasis recurrence is as important as the surgical treatment. For this reason metabolic evaluation and medical treatment of stone disease is extremely important. This study aimed to evaluate urological specialists' views of metabolic evaluation and medical treatment of urolithiasis. Thus, the main problems and the probable solutions about medical treatment and metabolic evaluation of urinary system stone disease can be evaluated.

Methods: The urologists working at Tekirdag were invited to the study. A face-to-face questionnaire, which was composed of three parts, was performed to the participants. In the first section, the demographic characteristics of the participants were evaluated. In the second and third sections, the approach of participants to metabolic evaluation and medical treatment in urolithiasis were investigated, respectively.

Results: A total of 29 urologist who routinely performed endourological surgery were included to the study. When we evaluated their endourological practice, $65.5 \%$ of the participants were performing 10-25 endourological surgery per month. When we asked the approach of participants about the metabolic evaluation, $34.5 \%$ reported that they did not perform metabolic evaluation to their adult patients and $65.5 \%$ did not perform to the children with urolithiasis. All participants believed the efficacy of medical treatment however, $66 \%$ of the participants were performing at less than half of their patients in clinical practice.

Conclusions: The clinical practice about metabolic evaluation, stone analysis and metaphylaxis were lower than expected. Most of the participants were not able to make metabolic evaluation and stone analysis. Further studies are needed to resolve the problems associated with metabolic evaluation and metaphylaxis administration.
\end{abstract}

Keywords: Urinary system stone disease, metabolic evaluation, metaphylaxis, stone analysis.

DOI: $10.5798 /$ dicletip.620323

Yazışma Adresi / Correspondence: Murat Akgül, Department of Urology, TekirdağNamık Kemal University, Faculty of Medicine, Tekirdağ, Turkey e-mail: drmuratakgul@gmail.com 


\section{Tekirdağ İlindeki Ürologlar Üriner Sistem Taş Hastalığında Taş Analizi, Metabolik Değerlendirme ve Metafilaksi Yapabiliyor mu?}

\section{Öz}

Giriş: Üriner sistem taş hastalığı coğrafyamız açısından endemik bir durum olup, ülkemizdeki üroloji uzmanlarının üriner sistem taş hastalığı ile ilgili tecrübeleri oldukça yüksektir. Üriner sistem taş hastalığının cerrahisi kadar bu hastalığın nüksünü engellemek de bir o kadar önemlidir. Bu bağlamda, taş hastalığının metabolik değerlendirmesi ve medikal tedavisi son derece önem taşımaktadır. Bu çalışmada, Tekirdağ ilinde çalışan üroloji uzmanlarının, üriner sistem taş hastalığında metabolik değerlendirme ve medikal tedaviye bakış açılarının değerlendirmesi amaçlanmıștır.

Yöntemler: Çalışmaya Tekirdağ ilindeki hastanelerde çalışan üroloji uzmanları davet edildi. Katılımcılara, toplam üç bölümden oluşan anket yüz-yüze uygulandı. Anketin ilk bölümde katılımclların demografik özellikleri değerlendirildi. Anketin ikinci ve üçüncü bölümlerde ise sırasıyla üriner sistem taş hastalığında metabolik değerlendirme ve medikal tedaviye yönelik katılımcıların yaklaşımları incelendi.

Bulgular: Klinik pratiğinde rutin endoürolojik cerrahi uygulayan toplam 29 üroloji uzmanı çalışmaya dahil edildi. Katılımcıların \%65,5'i ayda ortalama 10-25 endoürolojik cerrahi uygulamaktaydı. Metabolik değerlendirme ile ilgili görüşleri sorgulandığında katılımcıların \%34,5'i erişkinlerde ve \%65,5'i çocuk taş hastalarında metabolik değerlendirme uygulamadığını belirtti. Tüm katılımcılar üriner sistem taş hastalığında medikal tedavinin etkinliğine inanmaktaydı. Ancak katılımcıların $\% 66$ 'sı klinik pratikte medikal tedaviyi hastaların yarısından azında uygulamaktaydı. Bunun sebebi sorulduğunda katılımcıların yarısına yakını, metabolik değerlendirme için olanaklarının olmadığını belirtti.

Tartışma: Çalışmamızda, katılımcıların metabolik değerlendirme, taş analizi ve metafilaksi konusundaki uygulamalarının beklenilenden daha düşük olduğu görüldü. Katılımcıların çoğu metabolik değerlendirme ve taş analizi yapamadıklarını belirtti. Metabolik değerlendirme ve metafilaksi uygulanması ile ilgili problemlerin çözülmesine yönelik daha fazla çalışmaya ihtiyaç vardır.

Anahtar kelimeler: Üriner sistem taş hastalı̆̆ı, metabolik değerlendirme, metafilaksi, taş analizi.

\section{INTRODUCTION}

The incidence of renal stone varies all around the world and is defined as $15 \%$ in our country 1 . Because of this high rate, the urologists in our country have to deal with high number of renal stone patients and they are extremely skilled and well equipped for the evaluation and treatment of renal stone disease $\mathrm{e}^{2,3,4}$.

The urinary tract stone disease is a chronic process and proceeds with high recurrence rates $^{5}$. Five years recurrence rates of patients with residual stone were reported between 21$59 \%{ }^{6}$. Even, the recurrence rates of patients without residual stones were also high ${ }^{7}$. Therefore, it is important to determine the risk factors for recurrence and eliminate them. The urologists, who successfully treat urinary tract stone disease, also have an important role in eliminating the risk factors for recurrence. The urologists, who are capable of treating urinary tract stone disease, may abstain from stone risk analysis and stand clear for medical treatment of urinary tract stone disease. However, treating the existent renal stones may not be enough, determining the risk factors for recurrence and performing medical treatment for avoiding the recurrence must also be involved in the treatment strategy.

It is essential to understand the reason of why urologists beware of performing metabolic evaluation and medical treatment for the urinary system stone disease. By this way, we can try to solve the problem and integrate the treatment strategies to decrease the recurrence rates. In this study, we aimed to determine the point of view of urologist working at Tekirdağ, regarding urinary stone disease, stone disease metabolic evaluation and stone disease medical 
treatment (metaphylaxis). Therefore we try to answer the reasons regarding 'why the urologists can not perform stone analysis, metabolic evaluation and metaphylaxis in their routine clinical practice?'.

\section{METHOD}

All of the urologists working at the university, public and private hospitals in Tekirdağ were invited to the study. The urologists that did not want to participate the study were excluded. A face-to-face questionnaire was performed to the participants. The questionnaire had three parts. In the first part of the questionnaire, the demographic properties of participants were evaluated. The second and the third part of the questionnaire involved the participants' approach to metabolic evaluation and medical treatment of urinary system stone disease, respectively.

The data of the study was evaluated with proportional statistical analysis. We were not able to perform comparative statistical analysis, as the participant number was low. The study was approved by the Tekirdag Namik Kemal University ethical authority (Date: 28.12.2017 Number:2017/116/12/04).

\section{RESULTS}

A total of 32 urologists were invited to the study. As three urologists did not want to join, the study was finished with 29 (90.6\%) participants. According to the hospitals that participants were working, $4(13.8 \%)$ were at the university hospital, $15(51.7 \%)$ were at the public hospital, and 10 (34.5\%) were at the private hospital. When we evaluated the participants' specialty period, 3 (10.3\%) were <5years, 8 (27.6\%) were $5-10$ years, 14 (48.4\%) were $11-20$ years, $3(10.3 \%)$ were 21 30 years and $1(3.4 \%)$ was $>30$ years urologists.

The mean number of daily urological patients was $<10$ patients for $5(17.3 \%)$ participants, 10 25 patients for $7(24.1 \%)$ participants, 25-50 patients for $10(34.5 \%)$ participants and 50-100 patients for 7 (24.1\%) participants. The mean number of surgery/month was 1-10 surgeries for $2(6.9 \%)$ participants, 10-25 surgery for 19 (65.5\%) participants and 25-50 surgeries for 8 $(27.6 \%)$ participants. All of the participants in the study group were performing endourological surgery. The endourological equipment that the participant had at their clinics and the endourological stone surgeries that the participants were performing is shown in Figure 1.
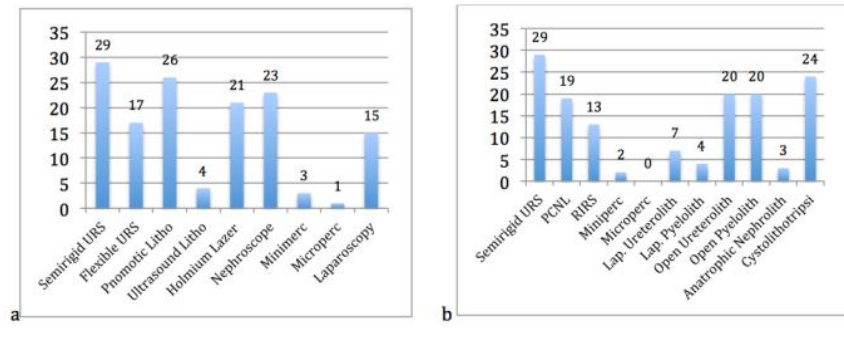

Figure 1- (a) The endourological equipment of the participants. (b) The endourological stone surgeries that participants perform.

The metabolic evaluation of the participants among the children and adult urinary system stone patients were demonstrated at Figure-2. The results demonstrated that 19 (65.5\%) participants did not perform a metabolic evaluation to children, and 10 (34.5\%) participants did not perform a metabolic evaluation to adult patients. The rate of stone analysis and medical treatment usage among the participants were also demonstrated at Figure 2.

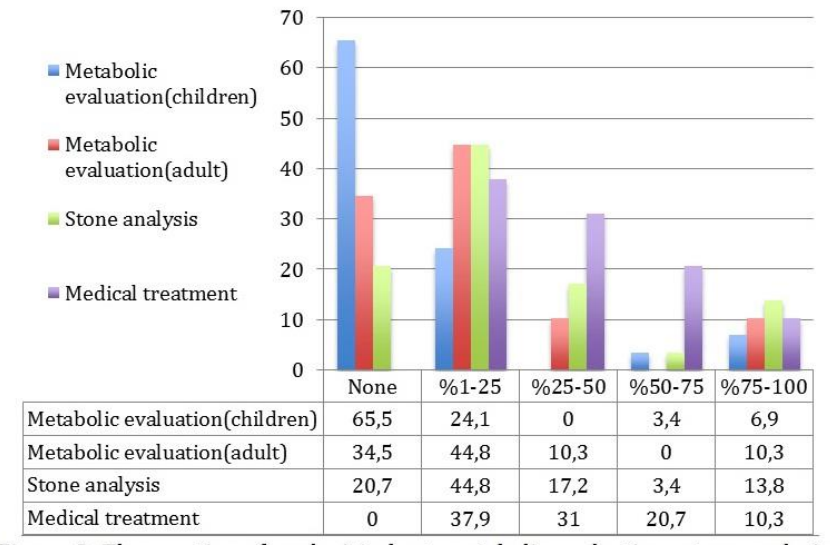

Figure 2. The practice of urologist about metabolic evaluation, stone analysis and medical treatment. 
All participants indicated that they believed the efficacy of medical treatment at the urinary system stone disease. On the other hand, two third of the participants were using medical treatment at $<50 \%$ of their patients. The ideas of the participants about this dilemma were shown in Figure 3. Nearly half of the participants reported that they did not have the opportunity to perform metabolic evaluation. Five (17.2\%) participants believed that medical treatment was not practical, 5(17.2\%) participants reported that they did not have time to perform metabolic evaluation/medical treatment and $9(31.0 \%)$ participants reported that they did not believe to patients' compliance to the treatment.

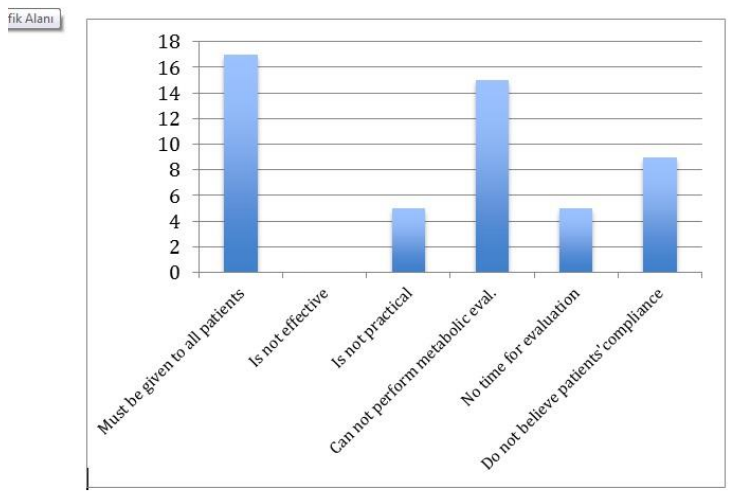

Figure 3. The view of urologists about medical treatment of urinary system stone disease

\section{DISCUSSION}

Prevention of urinary system stone disease recurrence is as crucial as the primary treatment ${ }^{8}$. For this reason, it is imperative to evaluate the risk factors for stone recurrence and eliminate them. The EAU guidelines recommend to perform a metabolic evaluation to urinary system stone disease patients according to risk analysis and make metaphylaxis if it is necessary. The guidelines also indicate that children with the urinary stone disease are high-risk patients for recurrence and metabolic evaluation should be performed to all children stone formers ${ }^{9}$.
Although the recommendations of the guidelines have been accurate, daily practice might differ. As it was shown in our study, nearly $90 \%$ of the participants were not performing a metabolic evaluation to $>75 \%$ of their child stone patients. Even $65 \%$ of the participants were not making any metabolic evaluation of these patients. The rate of the metabolic evaluation was similar for adult stone patients. Nearly $80 \%$ of the participants were not performing a metabolic evaluation to $>75 \%$ of their adult patients and almost onethird of the participants were not making any metabolic evaluation of their adult stone patients. The result documented that the recommendations of guidelines were not active in the daily practice of the participants ${ }^{10}$.

These findings might have several reasons. Metabolic evaluation during daily practice is a rigorous process. It needs significant cooperation between clinician, patient, and laboratory. Any problem in this cooperation might oppose the metabolic evaluation to be a standard procedure. On the other hand, high evidence-based data indicates the importance of the metabolic evaluation for high-risk urinary stone formers. For this reason, creating this cooperation is obligatory to put this recommendation into practice. The qualification of the laboratories for metabolic evaluation might be another challenging issue, but the biochemical variables of the metabolic evaluation are standard variables for a biochemistry laboratory. Most of the secondary and tertiary health center laboratories have the capacity to perform the metabolic evaluation. The only requirement is the cooperation between the clinician and the laboratory staff. If the quality of the laboratory is not enough for metabolic evaluation, a nearby-qualified center may be used. We believe that with proper cooperation and well-designed laboratory, metabolic evaluation of urinary stone patients may become a standard procedure. 
The urinary system stone analysis is a mandatory part of the metabolic evaluation. The EAU guidelines significantly recommend stone analysis to all first time stone patients. Even, most of the early and late recurrent urinary system stones have to undergo stone analysis. American Urological Association guidelines also strictly recommend stone analysis as soon as the stone was captured ${ }^{11}$. On the other hand, the rate of stone analysis may be less than expected in daily practice. Nearly $80 \%$ of the participants reported that they were performing stone analysis at $<50 \%$ of their urinary stone patients. Even $20 \%$ of the participants were not performing stone analysis to any of their patients. All of the participants in our study were performing stone surgery, but the rate of stone analysis was low. Although the findings of our study represented a small region, these results might be similar in other parts of our country. It is important to understand the reason for this situation. There are insufficient numbers of qualified stone analysis centers in our country, and it may be difficult for the urologists to get contact with these centers during their busy daily practice. On the other hand, informing the patients and guiding them for stone analysis is one of the primary duty of urologist. It is also very important for metaphylaxis and preventive medicine.

Medical treatment for appropriate patients may decrease the stone recurrence. On the other hand, it is crucial to define the proper patient and prevent overtreatment ${ }^{12}$. For this reason, evaluating the patients for risk analysis is very important. Stone analysis, metabolic evaluation and radiological findings are the primary determinants guiding the medical treatment. Performing medical treatment without evaluation may lead unnecessary treatment and cause drug overload. All of the participants in our study reported that they were performing medical treatment to their patients, but the rate of stone analysis and metabolic evaluation was meager, which was a dilemma. The reason for this dilemma may be related to the difficulties of performing metabolic evaluation and stone analysis on daily practice.

The idea of participants about medical treatment was also a part of our study. All the participants in our study reported that they believe the efficacy and necessity of metaphylaxis. On the other hand, the rate of metaphylaxis was low among the participants. When we asked the reason of this situation, nearly half of the participants reported that they did not have the opportunity to perform the metabolic evaluation. Besides this, some of the participants believed that the patient's adherence to treatment would be low and medical treatment was not practical. There were also some participants reporting that they were so busy to cooperate with patients for metaphylaxis. In clinical practice the view of urologists about metaphylaxis is lower than expected. However most of the participants think that metaphylaxis must be given to all patients that deserves. These data showed that organizing the qualified laboratories for metabolic evaluation and counseling clinicians about metaphylaxis might increase the rate of medical disease for high-risk urinary system stone patients.

There were some limitations of our study. As we designed the study in a city, the data were not able to indicate the perspective of the general population. For this reason, similar studies from different parts the country are needed to document the idea of urologists about metabolic evaluation and metaphylaxis. These data will be instrumental in understanding the problems and trying to solve them to activate metaphylaxis, which is an evidence-based treatment for the urinary system stone disease. Another limitation of our study was related to the design. We used a questionnaire in our study, which might be related to personal bias. On the other hand, the study population was urologists, who had high 
social status and were familiar with scientific studies. We believe that these properties of the participants would lower the possible personal bias. As there were limited numbers of participants in our study, we were not able to analyze the results according to demographic properties of the participants. Increasing the participant number with future studies may enable us to analyze the data.

In conclusions, the participants in our study were performing the metabolic evaluation, stone analysis, and metaphylaxis at less than expected at urinary system stone patients. Most of the participants were not able to make metabolic evaluation and stone analysis. All of the participants believed the efficacy of metaphylaxis, but they also had suspicions about the feasibility of metaphylaxis. It is essential to understand the problems related to stone disease metabolic evaluation and metaphylaxis and try to solve the issues because without an appropriate approach the treatment of urinary system stone disease will be incomplete.

Conflicts of interest: The authors have no conflict of interests to declare.

Financial Disclosure: The authors declared that this study has received no financial support.

\section{REFERENCES}

1. Akinci M, Esen T, Tellaloğlu S. Urinary stone disease in Turkey: an updated epidemiological study. Eur Urol. 1991; 20: 200-3.

2. Davarcı M, Rifaioğlu M, Yalçınkaya FR, et all. Üriner Sistem Taş Tedavisinde İki Senelik ESWL Sonuçlarının Değerlendirilmesi [Evaluation of the results of ESWL therapy in urinary system stone disease for two years] Dicle Med J. 2012; 3: 377-380.
3. Amasyalı AS, Ertek MŞ, Türe M, et all. The Effect of Preoperative and Intraoperative Clinical Findings on Success of Endoscopic Management of Ureteral Stone Dicle Med J. 2016; 43: 285-9.

4. Celik H, Ediz C, Çamtosun A, et all. Percutaneous nephrolithotomy in very elderly patients (Age 75 and Over). Dicle Med J. 2015;42: 506-9.

5. Romero V, Akpinar H, Assimos DG. Kidney stones: a global picture of prevalence, incidence, and associated risk factors. Rev Urol. 2010; 12: 86-96.

6. Osman MM, Alfano Y, Kamp S, et all. 5-year-follow-up of patients with clinically insignificant residual fragments after extracorporeal shockwave lithotripsy. Eur Urol. 2005;47: 860-4.

7. El-Nahas AR, El-Assmy AM, Madbouly $\mathrm{K}$, et all. Predictors of clinical significance of residual fragments after extracorporeal shockwave lithotripsy for renal stones. J Endourol. 2006;20: 870-4.

8. Yuvanc E, Yilmaz E, Tuglu D, et all. Medical and alternative therapies in urinary tract stone disease. World J Nephrol. 2015; 6-4: 492-9.

9. Türk C, Neisius A, Petrik A, et all. EAU Guidelines on Urolithiasis. European Association of Urology 2017.

10. Gambaro G, Croppi E, Coe F, et all.(Consensus Conference Group) Metabolic diagnosis and medical prevention of calcium nephrolithiasis and its systemic manifestations: a consensus statement. J Nephrol. 2016;29: 715-734.

11. Pearle MS, Goldfarb DS, Assimos DG, et all. Medical Management of Kidney Stones. American Urological Association 2014.

12. Ather H, Siddiqui I, Siddiqui $\mathrm{T}$, et all. Tailored metabolic workup for urolithiasis-the debate continues. J Coll Physicians Surg Pak. 2017; 27: 101-4. 